\title{
プローブパーソン調査のための逐次学習による 交通目的推定法
}

\author{
瀬尾 烹 1 ・日下部 貴彦 2 ・朝倉 康夫 ${ }^{3}$ \\ 1 正会員 東京工業大学研究員 環境・社会理工学院（ $\bar{T}$ 152-8552 目黒区大岡山 2-12-1-M1-20） \\ E-mail: t.seo@plan.cv.titech.ac.jp \\ 2 正会員 東京大学講師 空間情報科学研究センター（† 277-8568 千葉県柏市柏の葉 5-1-5） \\ E-mail: t.kusakabe@csis.u-tokyo.ac.jp \\ 3 正会員 東京工業大学教授＼cjkstart環境・社会理工学院（† 152-8552 目黒区大岡山 2-12-1-M1-20） \\ E-mail: asakura@plan.cv.titech.ac.jp
}

\begin{abstract}
プローブパーソン（PP）調查は GPS 等により交通行動情報を自動収集するため, 交通行動調査の長期間化や 精度向上につながると期待されている。しかし，トリップ目的は自動収集情報のみからは判別不能であり，被験 者の手入力負荷の小さい調査は依然難しい. 本研究は, トリップ目的を半自動的に収集し, かつ事前情報に頼 らない PP 調査として, 被験者の手入力による部分的な回答と, それに基づく逐次的な機械学習による目的推定 を組み合わせた「対話学習型 PP 調査」を提案する. その結果, 調査の進展とともに規則的トリップは自動で推 定されるようになり被験者の回答負荷が低減される一方，不規則トリップは手入力回答により高精度に把握可 能と考えられる．定式化した手法を既存 PP 調査結果上で再現し，その性質を検証した.
\end{abstract}

Key Words: probe person survey, activity travel survey, trip purpose, sequential learning, naïve Bayes classifier, smartphone

\section{1.はじめに}

プローブパーソン (PP) 調査とは, GPS などの機器 を用いた追跡型のヒトの行動調查手法である ${ }^{1), 2)}$. PP 調査は移動軌跡を自動で収集するため，被験者の手作 業によるコンピュータへの入力や紙面への記入に基づ くパーソントリップ（PT）調査と比較し，位置と時刻 に関するデータの精度が高く被験者の負荷が小さいと いう長所がある. そのため, パネル疲労 ${ }^{3)}$ を低減し, 交 通行動調査の長期間化と精度向上につながると期待さ れている.

しかし, PP 調査は全てのトリップ属性データを自動 で収集できるわけではない. 特に, 交通行動調査で重 要となるトリップの目的は, GPS の情報のみからは判 別不能である. そのため, トリップ目的を知るために は, PT 調査と同様に被験者による目的の入力が必要と なってしまい, 長期間に渡る精度の高い交通行動調査 は依然として難しい.

この問題を解決すべく, なんらかのオフラインの事 前情報と, GPS 情報などのオンラインで自動収集され る情報に基づき, トリップの交通目的を推定する研究 がなされている4)-10). ここで,「オフラインの事前情報」 としては, 既存 PT 調査データや地理情報がよく用いら れる. しかし，このような推定手法にはいくつか限界
があると考えられる．まず，信頼できる事前情報がな い場合には利用できない. そもそも PP 調査の目的は, この事前情報と同質のデータの収集である場合が多い ため, これは本質的な問題となりうる. また, 事前情報 に基づく推定結果は，それらの情報から導かれる典型 的な行動パターンに沿ったものとなる. そのため, 不 規則・非日常的なトリップの目的の推定, 長期間の変動 （個人・環境について）の捕捉, 個人属性の考慮が難し いと考えられる. 以上より, 調査の目的によっては事 前情報に基づく推定手法の利用は難しいといえる.

本研究では, 事前情報がなくても被験者の負担を抑 えてトリップ目的を収集できる長期間の PP 調査のため の手法を考える.そのために, 被験者の手入力による 部分的な回答と, オンラインでの機械学習を組み合わ せた「対話学習型 PP 調査」を提案する.

具体的には，まず，被験者のトリップ目的を推定す るモデルを用意する。そして，ある状況でのトリップ 目的の推定確度が低い場合, 被験者に入力を求め（対 話）そその結果を用い目的推定モデルを逐次的に更新す る (学習)。一方, 推定確度が十分高ければ, 推定結果 を真值とみなし, 入力を求めない. この調査手法の長 所として，以下のような性質が期待される：

- 調査の進展とともに目的推定モデルが精緻化され, 規則的なトリップ（例：通勤）は自動で推定され 
るようになり，被験者の回答負荷が低減する.

・推定の難しい不規則なトリップは, 入力による回 答により正確に把握できる.

・被験者毎に行動を学習できるため, 個人毎の性質 を考慮できる.

短所としては, 最低限の入力は避けられない点と, 誤 推定を完全には排除できない点がある.

本稿の目的は, 対話学習型 PP 調査手法の定式化と, その性質の定量的評価である. 具体的には，第 2 章に て, 被験者の行動履歴と対話に基づくトリップ目的の推 定・学習法を定式化する. 次に, 第 3 章にて, 既存 PP 調査結果を用いて本調查手法を検証し，その性質（例： 被験者の負担軽減度, 推定精度, 個人属性の考慮）を 分析する.

\section{2. 推定法}

\section{(1) コンセプト}

提案する手法では，現行 PP のように被験者が調査機 器を携帯するとする. 調査機器には, 機器により自動収 集可能な情報（例：時刻，位置）に基づきトリップ目的 をその確度と共に推定するモデルが組み込まれ，必要 に応じ被験者により操作可能とする．具体的な実装形 態としては，一般的なスマートフォン上にインストー ルされたアプリが考えられる. 調査は長期間（例：数 週間以上）に渡って実施されると想定する。

より具体的には, 調査機器はあるトリップが観測さ れた際，そのトリップの状況（自動収集可能な情報）と その時点でのトリップ目的推定モデルに従い, そのト リップ目的を自動で推定する. 推定結果の確度が高い 場合, 推定結果を行動履歴とみなして保存する. 一方, 確度が低い場合, 質問を発し被験者の入力を求め, その 回答を行動履歴として保存する (対話) 。そして, 得ら れた回答結果に基づき，モデルのパラメータを更新し， 以降の推定に用いる (学習). なお, モデルパラメータ の初期值には，無情報に相当する適当なものを与える とする.

本 PP 調査手法は以下のような挙動を示すと予想され る. まず, 調査の初期ではトリップ目的推定モデルの推 定確度が低いため，ほぼ全てのトリップにて質問を発 する. 仮に特定の状況で同一目的のトリップが繰り返 された場合（例：朝に自宅から職場へ向かう通勤トリッ プ）, 推定モデルはそのトリップの性質を学習できる. つまり, 時間の経過と共にその状況のトリップの目的 は確度良く推定されるようになり, 質問の発生量が大 きく減少したうえで, 精度の良い情報を得られる。一 方, 目的と状況が対応付けにくいトリップの場合（例： 休日の私用トリップ）は，推定確度が高くなりにくく，
質問発生量はあまり減少せず，結果的に精度の良い情 報を得られる. また, 調査が十分進展していても, こ れまでにない状況のトリップが観測された場合（例：平 日の休暇中の旅行トリップ），ほぼ必ず質問を発し，正 確な情報を得られる，要するに，習慣的なトリップの 目的は自動で推定し，不規則あるいは稀なトリップの 目的は被験者に質問することで, 回答負荷の低減と調 査精度の担保を図る手法といえる.

\section{(2) 対話学習型 PP 調査の流れ}

対話学習型 PP 調査の具体的な流れを記述すると, 以 下となる：

Step 1 被験者 $n$ の調查開始. 適当な初期学習用データ を与え，学習をリセット．トリップ回数 $i:=1$ とす る. 許容する推定䛊差 $p_{a f}$ (probability for allowable failure）を設定する.

Step $2 i$ 番目トリップの開始が判定された後，あらかじ め与えられた適当なタイミングで以下を実行する

Step 2.1【推定】この時点までに得られた学習用 データ $R_{n}^{i}$ と, $i$ 番目のトリップ状況 $Y_{n}^{i}$ に基 づき，同トリップの目的 $c_{n}^{i}$ を推定

Step 2.2【対話】トリップ目的推定結果の確度と $p_{a f}$ に基づき, トリップ目的を被験者に問う 質問を発生するか否か決定

質問を発した場合【学習】被験者の回答結 果を行動履歴とする．また，トリップ状 況と質問回答結果を学習用データ $R_{n}^{i} へ$ 加え $R_{n}^{i+1}$ とする.

質問を発しなかった場合 推定結果を被験者 の行動履歴とみなす

Step $2.3 i:=i+1$ し, Step 2 へ戻る

Step 3 被験者 $n$ の調查終了. 調查結果として被験者 $n$ の行動履歴の推定・回答結果を得る.

変数の定義は第 2.(3)a) にて詳述する．以上の流れをフ ローチャートとすると図-1 となる。

Step 2 のトリップ開始の判定は，位置データなどの センサ情報に基づく移動滞在判別手法 ${ }^{2)}$ を用いる. ト リップ目的を推定する「適当なタイミング」には，ト リップ $i$ の開始判定直後, 同終了判定直後, トリップ $i+1$ の開始判定直後などが考えられ，それぞれ利用可 能な「トリップ $i$ の状況」が異なる. この点は第 2.(4)b) 節にて考察する.

Step 2.1 の「トリップ状況」には，曜日，出発地の位 置情報, 出発時刻などが考えられる. 調査機器のセン サと機能によっては移動手段 ${ }^{11)}$ などの様々な情報が利 用可能と期待される. 


\section{(3) 定式化}

トリップ目的の学習・推定には単純べイズ分類器 ${ }^{12)}$ を用いる. 単純ベイズ分類器の利点として, 学習に必要 なサンプル数が少なくて済む点がある. そのため, 個人 毎の目的推定モデルを構築するために都合が良い，欠 点には, 変数間の条件付き独立を仮定しているため, 変 数間の複雑な相関関係を考慮できない点がある. その ため, 大量のデータが利用可能な場合には, 他の高度 な機械学習手法より精度が低い ${ }^{10)}$ が, 個人毎に行動パ ターンを学習する場合は大量のデータが得られるとは 考えにくい(詳しくは後述).

なお, 第 2.(3)b), 2.(3)c) 節の内容は, 通常の単純べ イズによる判別手法と同様であり, 既往研究でもオフ ライン情報に基づくトリップ目的の推定に用いられて いる ${ }^{13)}$.

\section{a) 定義}

トリップ目的の集合を $C=\{c\}$ とする. トリップ属 性（目的以外）の集合を $K=\{k\}$ とし，あるトリップ 属性 $k$ の取りうる值の集合を $X^{k}=\left\{x^{k}\right\}$ とする. ある トリップの状況を $Y=\left\{x^{k} \mid \forall k \in K\right\}$ とする1.

学習用データを $R_{n}^{i}=\left\{\left(c_{n}^{j}, Y_{n}^{j}\right) \mid j \in J_{n}^{i}\right\}$ と表記す る.ここで, $R_{n}^{i}$ はトリップ $i$ までに得られた個人 $n$ の 学習データ集合, $J_{n}^{i}$ は個人 $n$ がトリップ $i$ までに行っ たトリップのうち適当な一部の番号の集合 ${ }^{2}, c_{n}^{j}$ は個人 $n$ の $j$ 番目のトリップの目的, $Y_{n}^{j}$ は同状況である.

\section{b) 推定プロセス}

トリップ状況 $Y$ が観測されたとき，そのトリップの 目的が $c$ である確率は $P(c \mid Y)$ である.これはべイズの 定理より

$$
P(c \mid Y)=\frac{P(Y \mid c) P(c)}{P(Y)}
$$

と表せる.ここで単純べイズの仮定を置く.すなわち, ある $c$ のもとでの $Y$ の各要素 $x^{k}$ 間の相関を無視でき るとすると, 式(1)は

$$
P(c \mid Y)=\frac{1}{P(Y)} \prod_{k \in K} P\left(x^{k} \mid c\right) P(c)
$$

と変形できる.

1 分かり易さのため, 具体例を挙げて説明する.

まず, $C=\left\{c_{1}, c_{2}\right\}$ とし， $c_{1}$ は通勤， $c_{2}$ は帰宅とする. 次 に, $K=\left\{k_{1}, k_{2}, k_{3}\right\}$ とし, $k_{1}$ は曜日, $k_{2}$ は出発時刻, $k_{3}$ は 出発地とする. そして, $X^{k}$ について, 曜日は $X^{1}=\left\{x_{1}^{1}, x_{2}^{1}\right\}$ とし, $x_{1}^{1}$ は平日, $x_{2}^{1}$ は休日とする. 同じく, 出発時刻は $X^{2}=$ $\left\{x_{1}^{2}, x_{2}^{2}\right\}$ とし, $x_{1}^{2}$ は午前, $x_{2}^{2}$ は午後とする. さらに, 出発地 は $X^{3}=\left\{x_{1}^{3}, x_{2}^{3}, x_{3}^{3}\right\}$ とし,$x_{1}^{3}$ は自宅, $x_{2}^{3}$ は職場, $x_{3}^{3}$ はその 他とする.

以上の定義のもとでは, 個人 $n$ の $i$ 番目のトリップとして平 日・出発時刻午後・職場発という状況下の帰宅がなされたとす ると, これは $c_{n}^{i}=c_{2}, Y_{n}^{i}=\left\{x_{1}^{1}, x_{2}^{2}, x_{2}^{3}\right\}$ として表される. こ のとき, 本 PP 調査の想定では, まずは $Y_{n}^{i}=\left\{x_{1}^{1}, x_{2}^{2}, x_{2}^{3}\right\}$ の み観測され，目的 $c_{n}^{i}$ の值が推定対象となる．被験者に質問を 発した場合には, $c_{n}^{i}=c_{2}$ も観測される.

2 厳密には, 対話プロセスが発生し, 回答の得られたトリップの番 号の集合

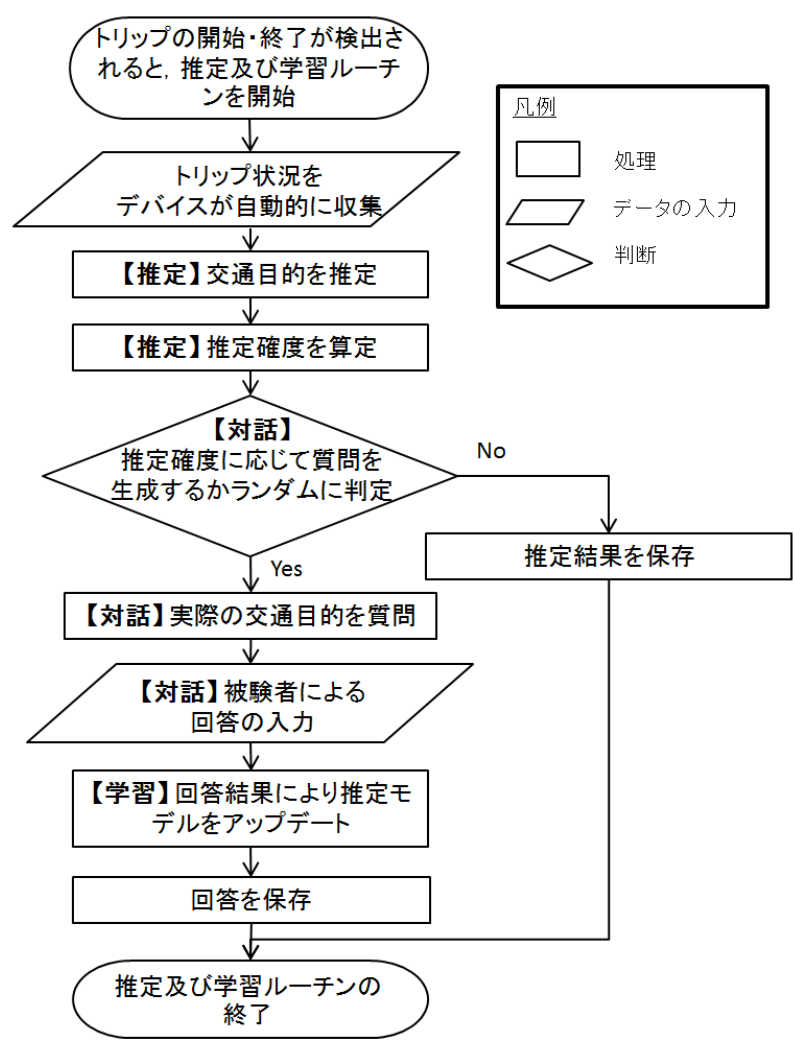

図-1 対話学習型 PP 調査のフローチャート

観測データに基づくトリップ目的推定問題とは， $Y$ が与件である場合に式 (2) を最大にするトリップ目的 $\hat{c}$ を求める問題を意味する. よって, これは

$$
\hat{c}=\underset{c \in C}{\operatorname{argmax}} \prod_{k \in K} P\left(x^{k} \mid c\right) P(c)
$$

と表せる.

\section{c) 学習プロセス}

式 (3) の計算（トリップ目的の推定）には $P\left(x^{k} \mid c\right)$, $P(c)$ が必要となる.これらを推定時 $i$ までに得られた データ $R_{n}^{i}$ に基づく学習により得たい（ $R_{n}^{i}$ の収集方法 は第 2.(3)d) 節にて後述する) .

学習データ $R_{n}^{i}$ に基づき $P\left(x^{k} \mid c\right)$ を求めると

$$
P\left(x^{k} \mid c\right)=\frac{\sum_{\left(c_{n}^{j}, Y_{n}^{j}\right) \in R_{n}^{i}} \gamma\left(c, x^{k}, c_{n}^{j}, Y_{n}^{j}\right)}{\sum_{z^{k} \in X^{k}} \sum_{\left(c_{n}^{j}, Y_{n}^{j}\right) \in R_{n}^{i}} \gamma\left(c, z^{k}, c_{n}^{j}, Y_{n}^{j}\right)}
$$

ただし

$$
\gamma\left(c, x^{k}, c_{n}^{j}, Y_{n}^{j}\right)= \begin{cases}1 & \text { if } c=c_{n}^{j} \text { and } x^{k} \in Y_{n}^{j} \\ 0 & \text { otherwise }\end{cases}
$$

となる. 式(4) は, 学習データ中のトリップ目的が $c$ で あった時に属性 $k$ の值が $x^{k}$ であった割合を意味する. 同様に, $P(c)$ は

$$
P(c)=\frac{\sum_{\left(c_{n}^{j}, Y_{n}^{j}\right) \in R_{n}^{i}} \delta\left(c, c_{n}^{j}\right)}{\left|R_{n}^{i}\right|}
$$

ただし 


$$
\delta\left(c, c_{n}^{j}\right)= \begin{cases}1 & \text { if } c=c_{n}^{j} \\ 0 & \text { otherwise }\end{cases}
$$

となる. 式(6) は, 学習データ中のトリップ目的が $c$ で あった割合を意味する。

\section{d) 対話プロセス}

学習データ $R_{n}^{i}$ は, 被験者の入力により収集する. す なわち, 推定結果 $\hat{c}$ の確度に応じて後述のルールに従 いランダムに質問を発し，その回答を学習データに加 えるとする，このとき, 確度が低いほど質問発生確率 が上がるものとする.

質問を発し回答があった場合, その回答 $c_{n}^{i}$ を真の卜 リップ目的とみなし， $Y_{n}^{i}$ と共に $R_{n}^{i}$ へ加える $\left(R_{n}^{i+1}=\right.$ $\left.R_{n}^{i} \cup\left\{\left(c_{n}^{i}, Y_{n}^{i}\right)\right\}\right)$. 質問を発しなかった場合, 推定結果 である $\hat{c}$ 真のトリップ目的とみなし, 学習データの 収集には関与しない $\left(R_{n}^{i+1}=R_{n}^{i}\right)$.

具体的には, $\hat{c}$ の確度は $P(\hat{c} \mid Y)$ と定義でき,

$$
P(\hat{c} \mid Y)=\frac{\prod_{k \in K} P\left(x^{k} \mid \hat{c}\right) P(\hat{c})}{\sum_{c \in C} \prod_{k \in K} P\left(x^{k} \mid c\right) P(c)}
$$

と表される. そして, 質問の発生確率 $p_{q}$ を

$$
p_{q}=\max \left\{0,1-\frac{p_{a f}}{1-P(\hat{c} \mid Y)}\right\}
$$

で与える. ここに, $p_{a f}$ は所与の許容誤判定率である. 式 (9) は, 対話プロセスの結果得られる最終結果は近似 的に確率 $p_{a f}$ で誤ることを意味する.

\section{(4) 考察}

\section{a) 手法の性質}

本手法では時間の経過とともに学習用データ $R_{n}^{i}$ のサ ンプル数が増加する. あるトリップ目的 $c$ と状況 $Y$ に 明確な関係がある場合, その $c$ についての確度 $P(\hat{c} \mid Y)$ は調査の時間とともに次第に大きくなり, 自動で推定 されるようになる. 逆に, 明確な関係が無い場合には, $P(\hat{c} \mid Y)$ は大きくならず，被験者に質問を発するが，正 確な回答を得られるため精度は悪化しない. このとき, $R_{n}^{i}$ は個人 $n$ 毎に用意されているため, 個人の特性を考 慮した推定が可能となる.

許容する推定䛊差率として $p_{a f}$ を与えている. 式 (9) から明らかなとおり, 一般に $p_{a f}$ が小さいほど質問発 生率 $p_{q}$ が大きく, $p_{a f}$ が大きいほど $p_{q}$ が小さくなる. つまり, 被験者の回答負荷軽減と推定精度の間にはト レードオフの関係がある. この点を考慮しつつ, $p_{a f}$ の 值は調査の目的に応じて調查設計者が決定する必要が ある. なお, $p_{a f}=0$ (䛊りを一切許容しない) とする と毎回質問が発生する. この意味で, 本 PP 調査の枠組 みは現行の通常の PP 調査を特殊な場合として包含して いるといえる.

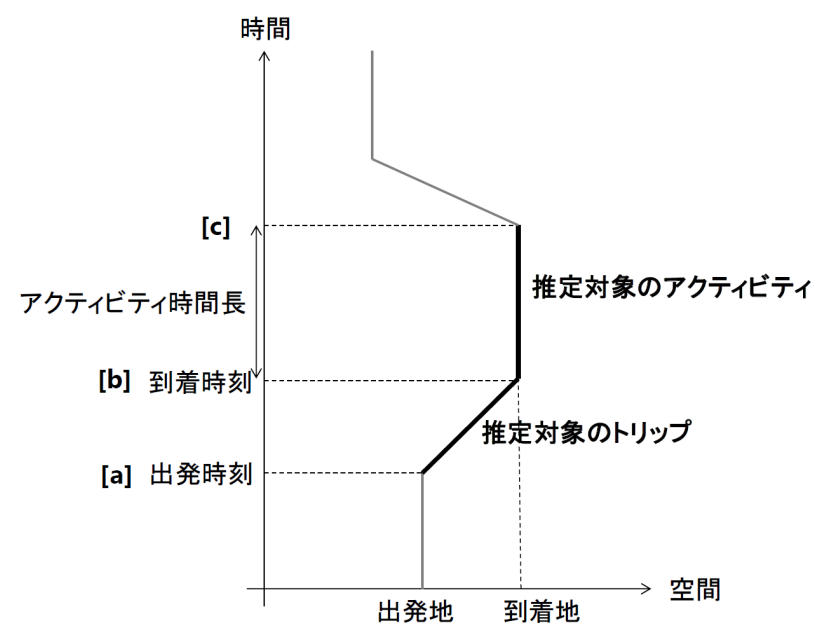

図-2 被験者の軌跡と質問タイミングの関係

\section{b) 実際の調査}

以上の議論では, 理想的な状沉を考え, 実際の PP 調 查で生じうる問題を無視していた。本節では, 実際の 調査の観点から見た本手法の特徴について述べる.

質問タイミングは調査の設計上重要である. 例えば, 利用可能なタイミングとして以下の 3 種が考えられる：

[a] 推定対象のトリップ開始時

[b] 推定対象のトリップ終了時

[c] 推定対象のトリップ直後のアクティビティ終了時

それぞれの時間関係を図-2に示す。これらのタイミン グ間では，推定に用いることのできる情報がそれぞれ 異なり，また被験者の回答負荷もそれぞれ異なる. すな わち, 時間軸上で未来にあるタイミングほど推定に用 いることのできる情報が多く，精度が高いと期待され る. 例えば, [c] の場合はトリップの到着地やアクティ ビティ時間長が既知になる。一方, 被験者の回答負荷 の観点からは, [b] はアクティビティ中に回答を求めら れ, [a] と [c] はトリップ中に回答を求められる. その ため, それぞれでアクティビティやトリップの種類に 応じて異なる回答負荷がかかると考えられる.

本手法はトリップの開始と終了を自動で判別する手 続き，いわゆる移動滞在判別を必要とする．この判別 はほぼリアルタイムに実行する必要がある. 移動滞在 判別手法は既往研究にて提案されており ${ }^{2)}$, ある程度高 精度での判定が可能であるが, 完全とはいえない. 移 動滞在判別に䛊差がある場合, 実際のトリップとは大 きく異なるトリップを認識したり, 実際のトリップを認 識しないなどが考えられる. 当然, そのような場合に はトリップ目的を適切に推定できない. そのため, 本 手法の性質に適した移動滞在判別手法を採用する必要 がある. 例えば, リアルタイム移動滞在判別ではトリッ プ終了の早期検知が難しい場合が多い.この観点から 
は, トリップ終了の早期検知に依存しない質問タイミ ングとして, トリップ開始時に目的推定・質問発生を する前述 [a] と [c] が有効と考えられる.

実際の調査では, 上記の回答負荷や移動滞在判別の 問題のために被験者が回答できない場合がありうる.こ のような場合, 必要に応じて, 完全な欠測值と扱うか, あるいは, 精度の低下を許容してその時点での学習モ デルに基づく推定結果を調査結果と扱うことができる. 単純ベイズは, 他の機械学習手法と比較し精度が低 い場合があるものの, 学習・推定に必要な計算量とサ ンプル数が非常に小さいという長所を持っている.こ の長所は本手法にとって本質的に重要である. まず, サ ンプル数が小さいため, 個人毎の特徵を学習するのが 容易である ${ }^{3}$. また, 逐次学習のための計算量が小さく, 高度な計算・データ処理能力がない携帯機器を用いた PP 調査への適用が容易である.

\section{3. 検証}

\section{(1) 検証法}

過去の交通行動調査で得られた実データを用いたシ ミュレーション分析により, 提案手法の定量的性質を実 証的に検討する. 本分析では, 当該データに含まれる トリップ属性を真值とみなし，これらのトリップに対 し第 2 章で述べた手法を適用し, その結果を分析する.

具体的には, データ中の各被験者に対し, 時系列順 に推定・対話・学習の各プロセスを実行する.トリップ 目的推定の際には，データ上として得られている既知 のトリップ状況を使用する. 対話プロセスで質問が発 生した場合には, データ上の目的の值を回答したとみ なす。そして，シミュレーション結果として得られた トリップ目的推定結果と, 元データ上の目的を比較し, 推定精度を検証する. あわせて, 提案手法によるトリッ プ目的の取得に関する特性, 被験者の回答負荷軽減の 度合い, それらに対する質問タイミングの影響, 被験 者毎の性質などについて分析する.

なお，提案手法の質問の発生は確率的に決定される. そこで, Monte Carlo シミュレーションにより被験者毎 に 1000 回の試行を行い, その平均やばらつきを用いて 評価する.

\section{a) データの概要}

2007 年に松山市にて実施された PP 調査（まつやま エコ交通 2000 人チャレンジ）の内， 12 月 17 日 12月 30 日の 14 日間に収集された 92 人 4120 トリップのデー タを用いる. データの技術的な詳細については付録 A を参照されたい．

\footnotetext{
3 あるヒトの一か月のトリップ数は通常百程度である. そのため, 本手法のような個人毎の PP 調查では, 一か月の調査でのサン プル数はせいぜい数十程度しか得られない。
}

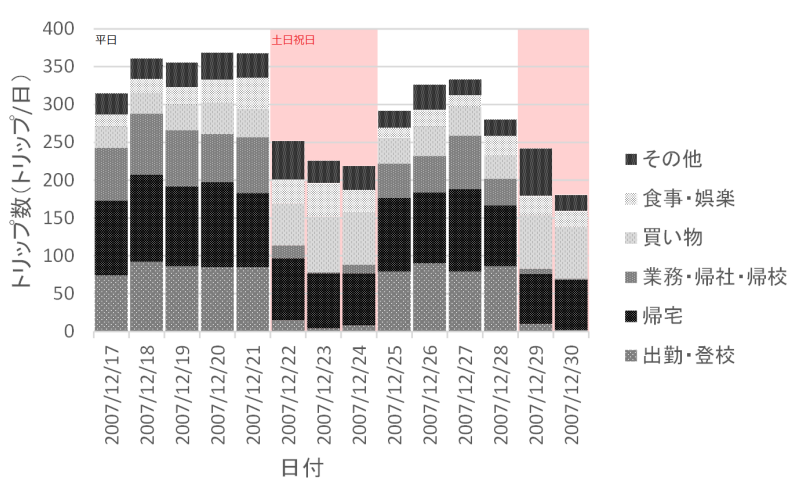

(a) 目的別トリップ数の推移

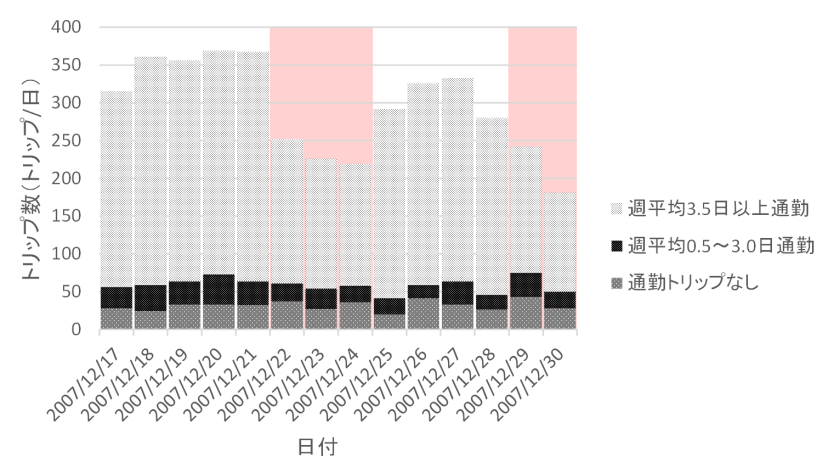

(b) 被験者属性別トリップ数の推移

図-3 トリップ数の時間推移

データの基礎集計結果を述べる. 図-3に被験者のト リップ特性を示す.なお, 図内のピンク色の背景は, 土 日祝日を示している (以下同様). 図-3aに各日でのト リップ数および交通目的の構成を示す. 土日祝日であ る 12月 22〜24 日及び $29 \cdot 30$ 日とこれら以外の平日で は, トリップ数および構成比に大きな違いがみられる. 特に土日祝日では, 出勤・登校および業務・帰社・帰校 が大きく減少し, 買い物が増加している傾向が読み取 れる.

図-3b は，被験者を週当たりの出勤・登校を目的とし たトリップを行った日数をもとに分類し，その分類別 に各日のトリップ数を示したものである. これは, 当該 データには被験者属性が含まれていなかったため, そ の代替を意図したものである. 週あたり平均 3.5 日以上 通勤している被験者は 73 人であり, 週 $0.5 \sim 3.0$ 日の被 験者は 12 人, 通勤トリップのない被験者は 7 人であっ た. トリップ数については, 通勤が週 3 日より多い被験 者は土日祝日にトリップ数が大きく変動する傾向にあ ることがわかる. 図-4に被験者毎の総トリップ数の分 布を示す．40４9トリップが最頻值となっており，こ れは約 3.2 トリップ/日に相当する. 週 0.5〜3.0 日の被 験者については, サンプル数が少なく, トリップ数の ばらつきが大きいことがわかる. 


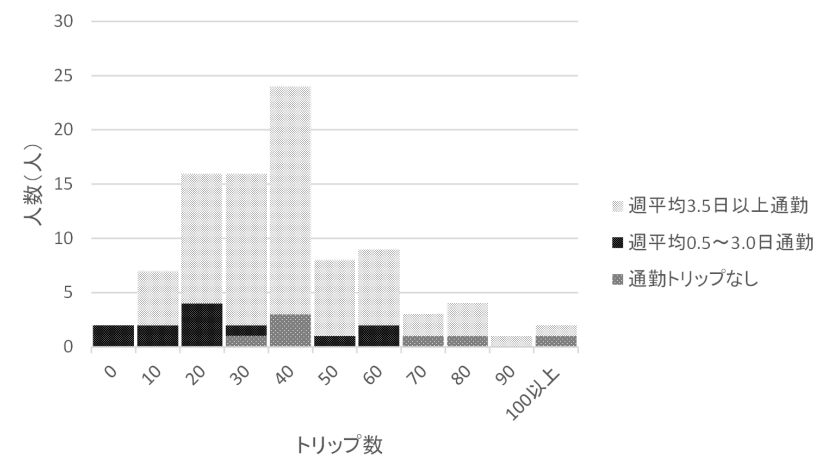

図-4 被験者属性別のトリップ数分布

\section{b) モデルの特定}

第 2.(3) 節での定式化は一般的なものであった．今回 の分析では，用いたデータの仕様に合わせ，モデルを 以下のように特定した。

トリップ目的集合 $C$ の要素は以下とする：

- 出勤・通学

- 帰宅

・業務・帰社・帰校

- 買い物

・食事・娛楽

・その他

質問タイミングとして第 2.(4)b) 節で述べた 3 種を考 え，それぞれについてトリップ属性 $K$ の要素を以下と する：

[a] トリップ開始時

・平日ダミー

・出発時間帯

- 出発地

[b]トリップ終了時

・平日ダミー

・到着時間帯

- 到着地

[c] アクティビティ終了時

・平日ダミー

・到着時間帯

- 到着地

・アクティビティ時間長

を考える，なお，以降の分析では，第3.(2)d) 節を除き ベースシナリオとして $[\mathrm{b}]$ を考える. 平日ダミーは, 平 日か土日祝日を区別するダミー変数である．出発・到 着時間帯は，1 日を 3 時間単位で区切った離散的な時刻 とした，出発・到着地は，出発・到着地点に該当する メッシュコード（7 ケタで定義される Geohash ${ }^{14)}$ ) とし

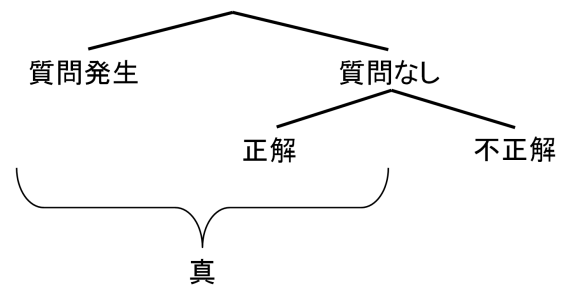

図-5 質問・正解・不正解・真の関係

た．このとき，1メッシュ当たりのサイズは概ね百数十 $\mathrm{m}$ 四方であり，日本全国で 80000 メッシュが定義され ているものとみなして計算した。

許容される誤判定率 $p_{a f}$ は，第 3.(2)d) 節を除きべー スシナリオとして $5 \%$ とする. 調査開始時の事前情報は 一様分布とする (無情報)。すなわち，すべての属性の 要素の值と目的の組み合わせが 1 回ずつ観測されてい る状況に相当する $R_{n}^{1}$ を与えた．この初期状態では，全 ての $P(\hat{c} \mid Y)$ の值が $1 /|C|$ となり, 推定確度が低いと判 定される.

\section{c) 推定手法の指標}

推定手法の性能を表す指標として，以下を定義する：

質問（率） 回答者に交通目的を問う質問が発生した卜 リップ（の全トリップに対する割合）

正解（率） 質問が発生せず，かつ交通目的を正しく推 定できたトリップ（の同割合）

不正解（率） 質問が発生せず，かつ交通目的を誤って 推定したトリップ（の同割合）

真（である割合） 最終的に正しい交通目的が得られた トリップ（の同割合）

正しい調査結果が得られる割合は，(真である割合) = (質問率 $)+($ 正解率 $)=1-$ (不正解率) であり，これが 高いほど調査者にとって望ましいといえる．被験者の 回答負荷は質問率が低いほど小さいといえる．以上の 関係を図-5 に図示する。

\section{(2) 検証結果}

本節では，調査期間と質問率の低減具合の関係，対 話・学習プロセスを経て得られる推定值の安定性, 質 問率・正解率の関係，トリップ目的や被験者のトリップ 特性による推定結果の特徵について結果を整理し考察 する.

\section{a) 全体的な傾向}

調査の進展と共に推定結果がどのように変化するかを 分析する. 図-6 は, 各日での質問率，正解率，及び不正 解率について, 1000 回の Monte Carlo シミュレーション 試行中でのそれぞれの 5\%タイル值，中央值，95\%タイ ル值を時系列順に示したものである. 平日だけに着目す 


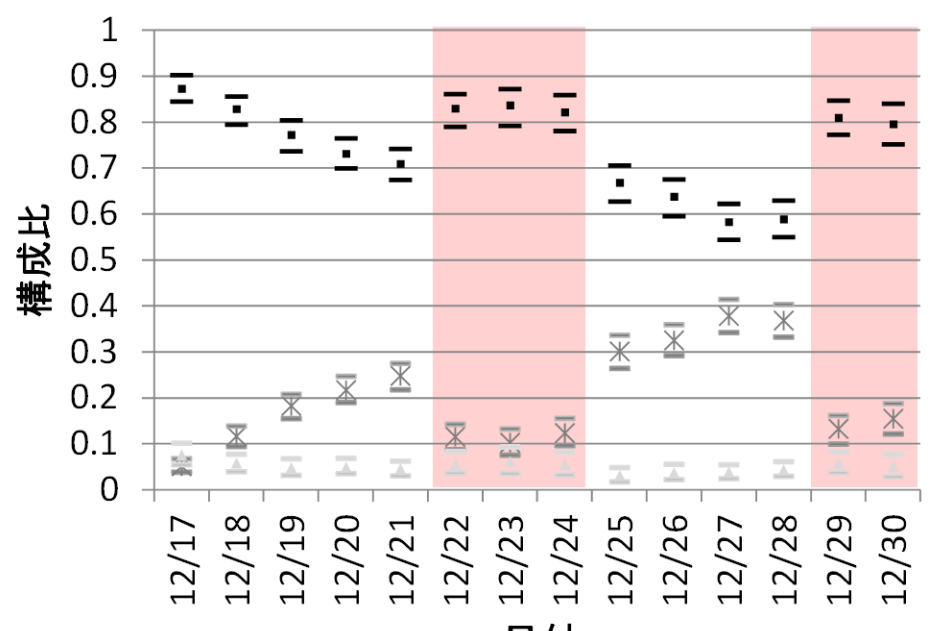

一質問率 (95\%タイル値)

・質問率 (50\%タイル値)

一質問率 (5\%タイル値)

- 正解率 (95\%タイル値)

* 正解率 (50\%タイル値)

- 正解率 ( $5 \%$ タイル値)

一不正解率 (95\%タイル値)

不正解率 (50\%タイル値)

一不正解率 (5\%タイル値)

日付

図-6 質問率・正解率・不正解率の時間推移

ると, 調査の日数経過とともに質問率が減少し, 正解率 が上昇している. 最終日の質問率の中央值は約 $58.9 \%$ と なっている. 同じく正解率は $36.7 \%$ である. 一方, 土日 祝日は平日と比較して質問率が高く, 休日の最終日の 中央値は $80.0 \%$ となっている. 誤判定率は, 平日休日関 わらず中央值の平均 $5.0 \%$ で推移しており, あらかじめ 設定した許容誤判定率 $p_{a f}=5 \%$ とよく一致している. 95\%タイル值と 5\%タイル值の差は, 質問率・正解率・ 不正解率いずれの結果も数パーセントと小さい值であ り, 本手法の挙動は安定しているといえる.

次に, トリップ目的推定モデルの性能について, 1 日 の学習によってどの程度性能が改善しているか, モデ ルの性能が十分な度合に達するまでどの程度の日数が 必要かを分析する. 図-7 は, ある時点での推定モデル が交通目的を正しく推定できる割合を，被験者毎の累 積分布として示している（分析手法の詳細は付録 B を 参照のこと). 言い換えると, この割合は, 仮にある日 にモデルの対話・学習を停止し以降全てのトリップの目 的を自動推定するようにした場合に，以降のトリップ 目的を正しく推定できる割合である4. パーセンタイル 值は被験者数に対する割合を意味する。例えば，7 日目 について，提案手法は 50\%の被験者に対して約 70\%以 上の割合で以降のトリップを正しく推定できる性能を 持ち，5\%の被験者に対しては約 $93 \%$ 以上の割合で正し く推定できる性能を持っている. 本図から, 提案手法 は調査の進展と共に性能がほぼ単調に向上するが, そ の向上速度は個人毎に大きく異なることがわかる.

第 2.(4)b) 節で述べたように, 何らかの事情により被 験者が回答できなかった質問は提案手法の推定結果に

\footnotetext{
4 実際には，提案手法はトリップ目的を正しく推定した場合にも 質問を発する可能性がある. そのため, 本割合と正解率は異な る概念であり，本図と図-6 は異なる結果を示している.
}

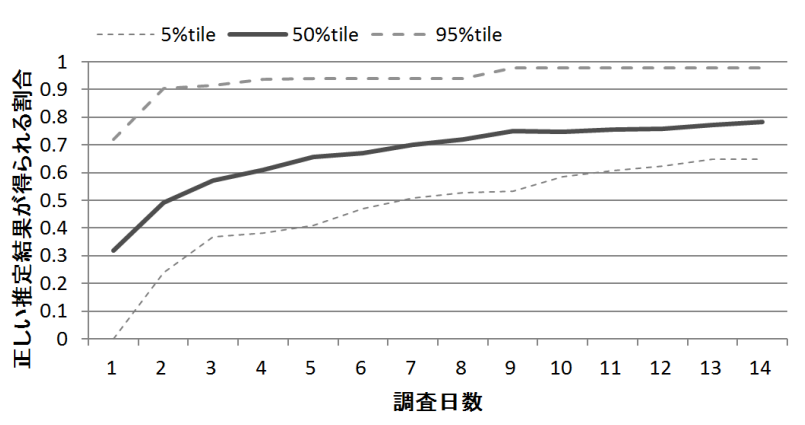

図-7 経過日数に対するトリップ目的推定モデルの学習進展 度

より補完できるが，その精度は図-7に示した結果から 見積もれる．例えば，仮に被験者がランダムに $50 \%$ の 質問に回答できないとすると，14 日目に回答し損ねた トリップ目的は平均して 70\%の精度で推定できる5.

\section{b) 被験者毎の傾向}

被験者毎の本手法の挙動をより細かく分析する.

図-8 に，被験者属性（通勤頻度）毎の提案手法の性 能の時間推移を示す. 通勤トリップの多い被験者の平 日トリップについては, 調査の進展と共に質問率が減 少し, 正解率が上昇している. それ以外の被験者や休 日トリップについては, サンプル数が少ないこともあ り，上述の傾向は弱い. 不正解率は概ね一定である.

図-9に, 被験者個人毎の推定結果の傾向を示す. 本 図は, 被験者毎の調査期間全体平均の質問率を綐軸, 同 じく真である割合を横軸にとった散布図として示して いる. 点が右に位置するほどその被験者に関する調査 結果が正確であり, 下に位置するほど回答負荷が小さ

\footnotetext{
5 質問に対して回答が少ない場合, その分学習速度が遅くなる. そ のため, 14 日目の学習状態は完全回答時の 7 日目 (=14 日 $\times$ $50 \%$ ）に相当し，図-7 の 7 日目の平均精度は $70 \%$ である.
} 

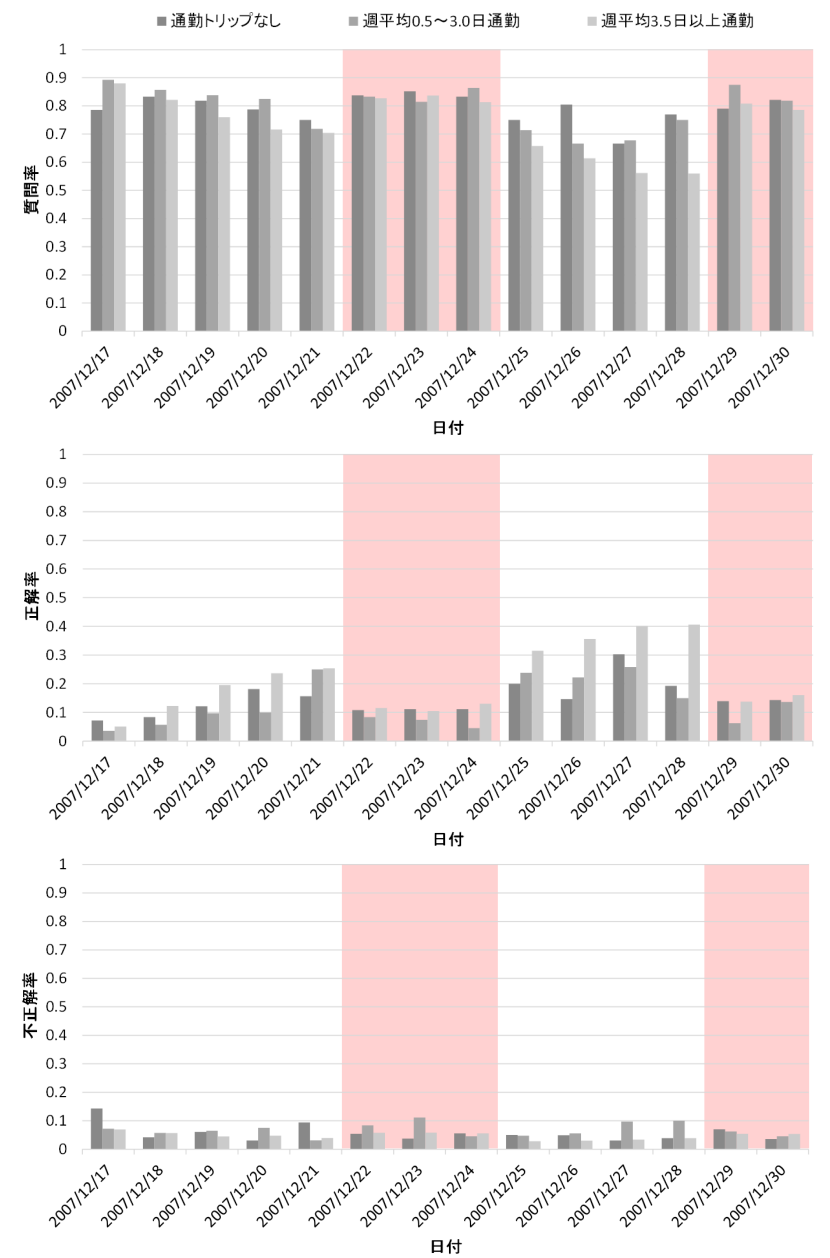

図-8 被験者属性毎の性能の時間推移

いことを意味する，そのため，点が右下に位置する（45 度線から離れている）ほど提案手法が効率的に働いて いるといえる. 一方, 点が 45 度線に乗っている場合, 質問がなかった場合には常に推定結果が外れているこ とを意味する。 なお, 調査の平日最終日の質問率は, 本 図の示す值（調査期間全体の平均值）より大幅に小さ いことに留意されたい。

図-9では, 質問率は被験者毎に異なっている一方, 真 である割合は全被験者でほぼ一定值 $\left(\simeq 1-p_{a f}\right)$ であ る.これは，個人の行動の規則性に応じて学習の精度 は異なるが，対話プロセスによって全被験者を通じて 一定の精度が確保されていることを意味する.

\section{c) 交通目的毎の傾向}

図-10に，交通目的毎の推定結果の傾向を質問率と真 である割合の散布図として示す，通勤，帰宅，業務卜 リップはいずれも質問率が比較的低く，かつ真である 割合が高い.これらのトリップは規則性が高いためと 考えられる. 一方, 買い物, 私用, その他トリップは 質問率が高く, かつ真である割合が低い，その理由は， これらのトリップは規則性が低く，その目的が互いに
混同されやすいためと考えられる.

\section{d) 許容誤差率・質問タイミングの影響}

調査者が与える要素, すなわち許容誤差率・質問夕 イミングが調査結果に与える影響を分析する.

図-11に，許容誤差率・質問タイミング毎の質問率と 真である割合の調査期間全体に渡る平均值を散布図と して示す. 本図からは許容䛊差率・質問タイミング毎の 特徵が明らかに読み取れる.すなわち, 許容䛊差率を 大きくすると，質問タイミングに関わらず質問率が大 きく減少し, 真である割合も許容誤差率を変えた分減 少する. また，質問タイミングを時間的に後にすると， 質問率が大きく減少することがわかる.

次に, 許容誤差率・質問タイミングが個人毎の推定結 果に及ぼす影響を分析する。図-12a に許容誤差率 $p_{a f}$ を $5 \%$ とした場合，15\%とした場合の間での個人毎平均 質問率の違いを比較する散布図を示す．また，図-12bに 質問タイミング [b], [c] に関して同様の図を示す.いず れの図でも, 個人の点は 45 度線より下にプロットされ ている，すなわち，それぞれの場合で許容誤差率 $15 \%$ お よび質問タイミング [c]の方が常に質問率が小さい.こ こから，図-11でみられた質問率に関する全体的な傾向 は, 個々人の結果にも共通してみられると確認できる.

\section{(3) 考察}

提案手法は全体的に第 2.(1) 節で述べた想定通りの挙 動を示しているといえる. すなわち, 調査の進展と共 に質問率が減少し, 被験者の回答負荷が低減していた. 推定確度が高い場合には質問を発さず，推定確度が低 い場合に質問を発生させる割合を増すことで，最終的 に得られる交通目的推定の精度を一定水準で保ってい た.この際，最終的な推定精度は調査の設計で与えた 值と概ね一致していた。

また，トリップの属性が提案手法の挙動に及ぼす影 響も定量的に示した。すすなわ，通勤のような規則的 なトリップがより高い精度で推定できた一方, 買い物, 食事・娛楽のようなトリップは質問率はあまり低下し なかった. これは，そのトリップの時間・場所の規則性 に起因すると考えられる.

所与とする許容誤差率や質問タイミングが提案手法 の性能に与える影響も分析した．許容䛊差率を大きく した場合，不正解率が大きくなる一方で質問率が減少 し回答負荷が減る現象を確認できた。質問タイミング については, [a]のトリップ前は特に精度が低い。これ はトリップ目的地の情報を使えないためと思われる．回 答負荷は [a] と [c] で同じと考えられるため, [a] は質問 タイミングとして望ましくないといえる。これらの知 見に基づき, 調査の目的と状況に応じた調查設計が可 能と考えられる. 


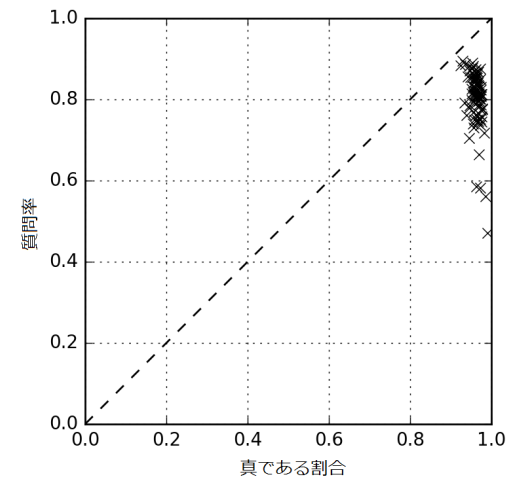

図-9 被験者毎の性能

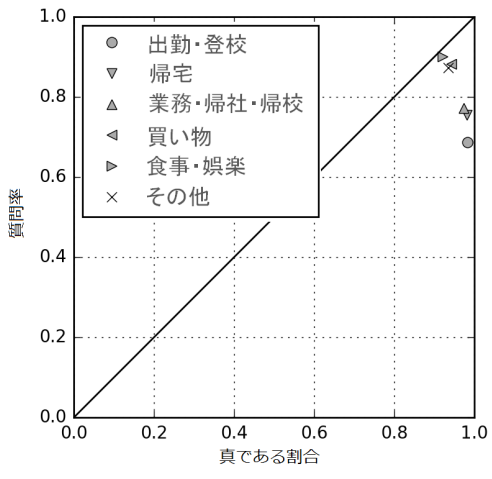

図-10 目的毎の性能

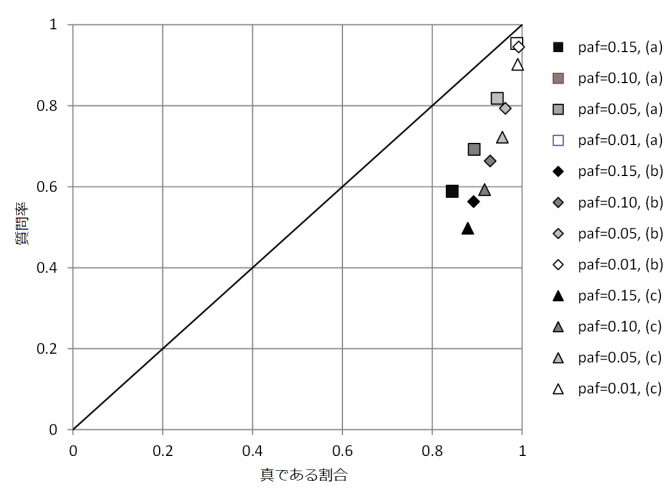

図-11 許容誤差率・質問タイミング毎の性能

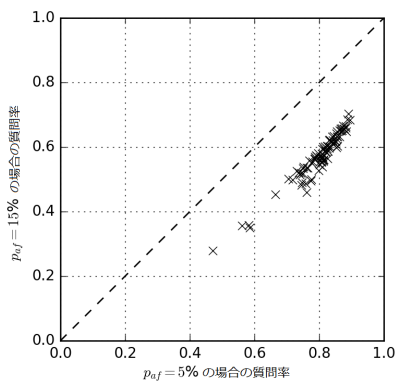

(a) 許容誤差率

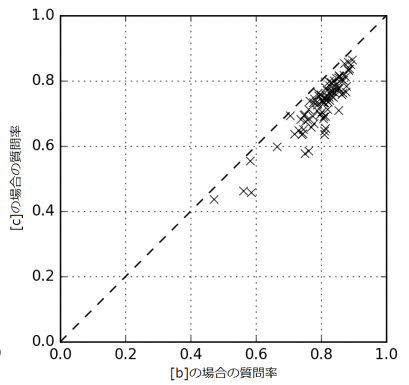

(b) 質問タイミング
図-12 許容䛊差率・質問タイミングの被験者毎への影響

上記の定性的傾向は，個人毎にも概ね成り立ってい ることが確認された，そのため, 提案手法は被験者の 属性によらずに（個人間の差こそあれ）回答負荷を低 減させ, かつ, ほぼ設計通りの精度の調查結果を得ら れた. よって，個人の異質性を考慮した調査が可能と いえる. これは, 提案手法が被験者毎に目的推定モデ ルを用意し, その行動パターンを学習しているためと 考えられる.

\section{4. おわりに}

本研究では, 事前情報に頼らず，かつ被験者の回答 負荷を低減する PP 調査手法として「対話学習型 PP 調 査」を提案した。これは, 被験者の入力による部分的 な回答と, オンラインでの機械学習を組み合わせ, 被 験者のトリップ目的を半自動的に推定する手法である. これにより, 調査の進展とともに典型的なトリップ状 況を学習し, 被験者の回答負荷を低減できると期待さ れる. 具体的には, 逐次学習型の単純べイズ分類器と して手法を定式化した.

既存の PP 調査結果上での検証の結果，提案手法は推 定精度を担保しつつ被験者の回答負荷を低減できるこ とを確認した．想定通り，通勤のような規則的なトリッ
プが自動推定され，娛楽のような不規則なトリップは 質問される場合が多いことが確認された。 さらに，以 上の定性的傾向は全ての被験者に共通してみられ, 個 人毎の属性を考慮できていた.

ただし, 本研究の検証用データの調査期間は 2 週間 のみであり, 学習期間に限りがあるといえる. より長 期間の調査により，質問率がさらに低減するかなどを 検証する必要がある.

現在, 本研究の成果に基づき, 提案手法をスマート フォン上に実装する作業を進めている. 今後, 試行的 に実 PP 調査へ適用し, 提案手法の実際の性質を検証す る予定である.

謝辞：「まつやまエコ交通 2000 人チャレンジ」に伴 う PP 調査のデータの使用に当たり, 東京大学の羽藤英 二教授, 松山市の石井朋紀氏, 復建調査設計（株）の森 三千浩氏に多大なご協力をいただきました。本研究は JSPS 科研費 26220906 「移動体観測に基づく交通ネット ワークの動的リスクマネジメント」の助成を受けたも のです．ここに謝意を表します。

\section{付録 A 検証に用いたデータの詳細}

2007 年度に松山市にて実施された PP 調査（まつや まエコ交通 2000 人チャレンジ) でのデータを使用した. この調査は, 第 1 期として 2007 年 10 月 27 日 (土) 12 月 9 日 (日), 第 2 期として同年 12 月 15 日 (土) 2008 年 2 月 3 日 (日) に実施された。これらの期間のうち, 第 1 期： 10 月 29 日 11 月 11 日，第 2 期： 12 月 17 日 12 月 30 日に日常行動データが収集された. 本研究では, サンプル数の多い第 2 期の日常行動データを用いる.

本研究での対話・学習プロセスの検証には, 一定期 間継続してトリップが観測されていること, 及び交通 目的などの情報が漏れなく記述されている必要がある. そのため下記の手順でデータクレンジングを行った. ま ず,「(i) 交通目的・到着地・到着時刻のいずれかの情報 
が記述されていないトリップを除去」した。このうえ で,「(ii) 最初と最後のトリップを行った日の間隔が 10 日未満の被験者を除去」し,「(iii) トリップを行った日数 に対する帰宅回数の比率が 0.8 未満の被験者を除去」し た. (ii) は十分な日数調査に参加した利用者を抽出する ことを意図したものであり，(iii) はできるだけ正確な記 述をしている被験者を抽出することを意図したもので ある. 本クレンジングの結果, 元データの 5329 トリッ プから, 4120 トリップ 92 人が抽出された.

\section{付録 B モデル学習速度分析の詳細}

本分析では，まず，被験者毎に500 回の Monte Carlo シミュレーションを行い, 被験者毎に 500 通りの学習 状態系列を作成する。 なお, 学習状態系列は, 各日終 了時点でのトリップ目的推定モデルのパラメータを格 納したものである，そして，各学習状態系列のトリッ プ目的推定モデルに対して学習状態の評価を行う。具 体的には, 該当する被験者の全トリップのデータから 100 トリップを復元抽出し, これらのトリップに対して トリップ目的を推定し, 各学習状態での各トリップ終 了時での的中率を求める. そして, それぞれの被験者 に対するシミュレーション結果を用い, 調査日数ごと にまとめ的中率の分布を求める.

\section{参考文献}

1) 大森宣暁, 室町泰徳, 原田昇, 太田勝敏: 交通行動調査へ の GPS の適用可能性に関する調査, 第 18 回交通工学研 究発表会報告, 1998.

2）朝倉康夫, 羽藤英二, 大藤武彦, 田名部淳: PHS による位 置情報を用いた交通行動調查手法, 土木学会論文集, No. 653/IV-48, pp. 95-104, 2000.

3) 北村隆一, 藤井聡, 山本俊行: 離散時間パネル調査の調 査期間, 調査間隔, 標本数の最適化, 土木学会論文集, No. 681/IV-52, pp. 13-23, 2001.
4) Wolf, J., Guensler, R. and Bachman, W.: Elimination of the travel diary: Experiment to derive trip purpose from global positioning system travel data, Transportation Research Record: Journal of the Transportation Research Board, No. 1768, pp. 125-134, 2001.

5) Shen, L. and Stopher, P. R.: Review of GPS travel survey and GPS data-processing methods, Transport Reviews, Vol. 34, No. 3, pp. 316-334, 2014.

6) Gong, L., Morikawa, T., Yamamoto, T. and Sato, H.: Deriving personal trip data from GPS data: A literature review on the existing methodologies, Procedia - Social and Behavioral Sciences, Vol. 138, pp. 557-565, 2014.

7) 塚本健太郎, 佐藤仁美, 森川高行: GPS やコンテクスト データを活用した行動目的の推定手法に関する研究, 土 木計画学研究・講演集, Vol. 50, 2014.

8) Kim, Y., Pereira, F. C., Zhao, F., Ghorpade, A., Zegras, P. C. and Ben-Akiva, M.: Activity recognition for a smartphone based travel survey based on cross-user history data, 22nd International Conference on Pattern Recognition, pp. 432437, 2014.

9) 金森亮: スケジュールデータによる移動情報の精度検証, 土木計画学研究・講演集, Vol. 53, 2016.

10) Feng, T. and Timmermans, H. J. P.: Comparison of advanced imputation algorithms for detection of transportation mode and activity episode using GPS data, Transportation Planning and Technology, Vol. 39, No. 2, pp. 180-194, 2016.

11）中村英夫, 宮下浩一, 羽藤英二, 岸井隆幸: パーソントリッ プ調査のための加速度センサを活用した Random Forest による移動手段推定手法, 交通工学論文集, Vol. 1, No. 5, pp. 10-18, 2015.

12) Rish, I.: An empirical study of the naive Bayes classifier, IJCAI 2001 Workshop on Empirical Methods in Artificial Intelligence, Vol. 3, pp. 41-46, 2001.

13) Kusakabe, T. and Asakura, Y.: Behavioural data mining of transit smart card data: A data fusion approach, Transportation Research Part C: Emerging Technologies, Vol. 46, pp. 179-191, 2014.

14) Niemeyer, G.: Geohash, 2008. http://geohash.org/

\title{
TRIP PURPOSE ESTIMATION METHOD FOR PROBE PERSON SURVEY USING SEQUENTIAL LEARNING
}

\author{
Toru SEO, Takahiko KUSAKABE and Yasuo ASAKURA
}

Probe person survey has received great deal of attentions, as it can automatically collect traveler's spatiotemporal traces using sensors like GPS, making a long-term travel survey easier. However, it is still difficult to collect all of the survey results automatically, because trip purpose-one of the most important characteristics of travel — is not possible to be identified based on such sensor data itself, making a long-term survey costly. This study proposes trip purpose estimation method based on automated sensor data and minimal manual questionnaires, in order to reduce survey burden on respondent and enable a long-term survey. In the proposed method, trip purpose is estimated by a classifier with sequential learning. Specifically, if the estimation confidence is high enough, the estimation result is considered as a survey result. Otherwise, the method asks actual trip purpose to the respondent, and then manually answered trip purpose is used to update the classifier. As results, the method is expected to reduce survey burden on respondents by automatically estimating purposes of recurrent trips, while keep data quality by asking purposes of irregular trips. Empirical features of the proposed method is validated by emulating the method on actual survey data. 